\title{
The gut microbiome - a new target for understanding, diagnosing and treating disease
}

\author{
Jeroen Raes \\ From Genes and nutrition, is personalised nutrition the next realistic step? \\ Brussels, Belgium. 25 April 2014
}

The functioning of the human body constitutes a complex interplay of human processes and 'services' rendered to us by the 1000 trillion microbial cells we carry. Disruption of this natural microbial flora is linked to infection, autoimmune diseases and cancer, but detailed knowledge about our microbial component remains scarce [1].

Recent technological advances such as metagenomics and next-generation sequencing permit the study of the various microbiota of the human body at a previously unseen scale. These advances have allowed the initiation of the International Human Microbiome Project, aiming at genomically characterizing the totality of human-associated microorganisms (the "microbiome") [2].

Here, I will present our work on characterizing the human intestinal flora based upon the analysis of highthroughput meta-omics (metagenomics, metatranscriptomics, metaproteomics) data. I will show how the healthy gut flora can be classified "enterotypes" that are independent from host nationality, age, BMI and gender, but linked to nutrition [3]. I will also show how metagenome-wide association studies (MGWAS) can lead to the detection of diagnostic markers for host properties and disease (e.g. in IBD, diabetes and obesity), and aid in further understanding on how the gut flora disturbances contribute to these pathologies. Finally, I will illustrate how gut microbiotabased treatment strategies are emerging, for example through Faecal Microbiota Transplantation (FMT).

\section{Published: 6 June 2014}

\section{References}

1. Hildebrand F, Nguyen TLA, Brinkman B, Yunta RG, Cauwe B,

Vandenabeele $P$, Liston A, Raes J: Inflammation-associated enterotypes, host genotype, cage and inter-individual effects drive gut microbiota variation in common laboratory mice. Genome Biology 2013, 14.

Correspondence: jeroen.raes@med.kuleuven.be

Department Microbiology \& Immunology KU Leuven, B-3000 Leuven, Belgium

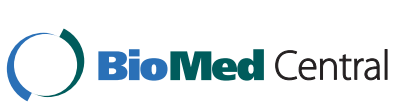

(c) 2014 Raes; licensee BioMed Central Ltd. This is an Open Access article distributed under the terms of the Creative Commons Attribution License (http://creativecommons.org/licenses/by/4.0), which permits unrestricted use, distribution, and reproduction in any medium, provided the original work is properly cited. The Creative Commons Public Domain Dedication waiver (http://creativecommons.org/publicdomain/zero/1.0/) applies to the data made available in this article, unless otherwise stated.
2. Qin JJ, Li YR, Cai ZM, Li SH, Zhu JF, Zhang F, Liang SS, Zhang WW, Guan YL, Shen $\mathrm{DQ}$, et al: A metagenome-wide association study of gut microbiota in type 2 diabetes. Nature 2012, 490:55-60.

3. Arumugam M, Raes J, Pelletier E, Le Paslier D, Yamada T, Mende DR, Fernandes GR, Tap J, Bruls T, Batto JM, et al: Enterotypes of the human gut microbiome. Nature 2011, 473:174-180.

doi:10.1186/2049-3258-72-S1-K3

Cite this article as: Raes: The gut microbiome - a new target for understanding, diagnosing and treating disease. Archives of Public Health 2014 72(Suppl 1):K3.
Submit your next manuscript to BioMed Central and take full advantage of:

- Convenient online submission

- Thorough peer review

- No space constraints or color figure charges

- Immediate publication on acceptance

- Research which is freely available for redistribution
- Inclusion in PubMed, CAS, Scopus and Google Scholar 